\title{
THE CONSERVATION OF GRASS FOR FEEDING PURPOSES IN AGRICULTURE ${ }^{1}{ }^{2}{ }^{2}$ )
}

\author{
N. D. DIJKSTRA \\ State Agricultural Experimental Station, Hoorn
}

In every good conservation method an attempt is made to bring the grass as quickly as possible to such a state as to arrest the activity of the enzymes and hence the respiration, and to prevent the large number of bacteria and moulds always present in grass from exerting a harmful effect.

The various conservation methods may be classified in three main groups:

1. haymaking

2. artificial drying

3. silage making.

1. Haymaking. In a good natural drying process in which use is made of solar radiation and wind, the moisture in the grass is evaporated to such an extent that the hay thus obtained, is unsuitable as a substrate for the bacteria.

This prevents further conversion by bacteria, and at the same time the enzymes become inactive.

In the case of haymaking in the field the following losses may be distinguished :
a. Respiration losses,
b. Mechanical losses,
c. Losses caused by rain,
d. Losses caused by the increase of the crude fibre deduction.

But when the drying has not been completely successful, there will either be subsequent fermentation in the haystack, or the hay will be a good substrate for moulds.

In this case we should add to the losses referred to above:

e. Storage losses.

We will now discuss these various types of loss in turn.

\section{a. Respiration losses}

When the grass is cut changes in the plants involving losses will occur at an early stage. The cut plants are still living and consequently respiration is still continuing for some time. Since carbohydrates are oxidized to $\mathrm{CO}_{2}$ and water by this process, respiration losses will be mainly related to the $\mathrm{N}$-free extract. The losses will be highly dependent on the rapidity of drying. The longer the drying the greater will be the losses.

There is, however, a further factor influencing respiration losses, viz. the temperature. The respiration intensity increases very rapidly with the temper-

1) Received for publication May 27, 1957.

2) Special University Lecture held on 16 May 1957 at the Agricultural College of the University of London at Wye College, Kent. 
ature. Consequently respiration losses will be much greater in warm and humid weather than in cold weather (29).

Generally speaking there were no protein losses in the trials, which only related to respiration. According to Crasemann (5) there is also, however, a small loss of protein caused by an enzymatic breakdown by which ammonia is formed.

\section{b. Mechanical losses}

By mechanical losses is meant the losses caused by working in the hay, for instance turning, shaking, etc. As a result of this, tender, valuable parts of plants are broken off and crushed. The drier and more brittle the hay is at this period the greater are such losses. But the kind of material also has a great influence; if a crop is rich in fine, tender leaves more of it will be crushed, and consequently mechanical losses will be lower in the case of grass than in the case of the various leguminous crops. Hence in the case of grass the losses will be higher, when it has a higher percentage of clover. Moreover these losses will depend on the stage of growth: the younger and leafier the grass the greater will be the losses. Since the finest, easily digestible parts of the plants are lost by crushing, the losses of digestible components and starch equivalent will be greater than the dry matter losses.

\section{c. Losses caused by rain}

These losses will depend on the amount of rain, the duration of the rainy period, the temperature and the botanical composition. They will also depend on the degree of wilting of the plants when the grass is moistened by rain. As in the case of mechanical losses, the effect will be greatest when the hay is already partly dry. The outermost layer of plants and especially of grasses, has a waxy consistency which prevents water from penetrating. Consequently rain falling on freshly cut grass will only cause slight damage, but when the hay is already partly dry and the walls of the cells have already lost their selective permeability rain may cause a great deal of harm.

Since rain washes out the most soluble, and hence the easily digestible components, the digestibility of the remainder will be lower. But the great losses which occur in rainy weather are not only due to washing. In wet and humid weather the plants are slow to die, so that respiration losses will be greater. Moreover wet hay requires more labour, and this also increases the mechanical losses.

Finally, wet hay provides favourable growing conditions for bacteria and moulds which use easily digestible feedingstuffs as their medium, and this also has a bad effect on the odour and flavour of the hay.

\section{d. Losses caused by the increase of the crude fibre deduction}

The digestion of a dry roughage such as hay requires more energy than the digestion of a soft, humid roughage such as grass. Hence, of the gross energy provided by hay less will be available for maintenance and production than in the case of grass, and we therefore have to give hay a lower "value number" than grass. According to Kellner (22) the best way to do this is to make a deduction of 0.29 on the theoretical starch equivalent in grass and of 0.58 on that in hay for each per cent of crude fibre in the fodder. 


\section{e. Storage losses}

The conversions in the hay, and consequently the losses, are not over when the hay has been stacked. In many cases there will even be some heating in the hay soon after it has been stacked. The degree of heating depends on the quality of the hay, the rapidity of the drying process, and especially on the moisture content of the stored hay.

The heating of hay is believed to be mainly owing to a chemical oxidation process, started by respiration of the still living cells and the activity of the micro-organisms. As mentioned earlier, the easily digestible carbohydrates are attacked by respiration. In bacterial conversions also there will be a loss of the most valuable components. The more the temperature rises the greater will be the amount of material oxidized and the higher will be the losses. These losses will bear chiefly upon the most digestible components.

But in many cases some heating is considered desirable as a part of the moisture in the hay is thereby evaporated, thus favouring the tenability of the hay, while slight heating also improves the palatability and smell. But such heating should not be excessive, since a high temperature has an adverse effect on the digestibility of the different components, and especially on that of the protein.

A recent study of the digestibility of various lots of more or less heated hay $(19,20)$ provided us with useful data as to how the digestibility of the various components was reduced by heating.

In many cases there was a very great decrease in the digestibility of the protein. With slight heating the decrease in the dig. crude protein content was about $25 \%$, with moderate heating about $55 \%$, with intense heating more than $80 \%$, and with very intense heating more than $90 \%$. Usually there was no great decline in the digestibility of carbohydrates; it was only with heavy heating that there was a marked decline. Consequently the decrease in the starch equivalent was smaller; with slight heating it was about $7 \%$, with moderate heating about $18 \%$, with intense heating about $34 \%$, and with very intense heating about $50 \%$.

These decreases in feeding value were found in the part of the hay in the haystack that had been exposed to such heating. In the rest of the haystack there was not of course such intense heating, and in many cases the edges of the haystack had not been heated at all. Hence spread over the entire haystack, the decrease in feeding value is not so considerable as the said figures would indicate. This does not alter the fact that intense heating, or even moderate heating, leads to a considerable decrease in feeding value.

It was impossible in these trials to determine the total storage losses. This has been done in a number of trials at the Experimental Station at Hoorn $(1,9)$ in which in most cases there was little or no heating of the hay, and in one or two cases only slight heating.

In these lots there was found to be a good correlation (10) between the dry matter content of the hay when stacked and the dry matter losses during storage in the haystack.

When the stacked hay contains $85 \%$ of dry matter the dry matter losses during storage will be about $1.7 \%$, with $80 \%$ of dry matter about $3.3 \%$, and with $75 \%$ about $5 \%$.

Since hay dried on racks or pyramids is usually less humid storage losses 
will be smaller than in the case of hay made on the ground. In our trials $(1,9)$, however, these differences were only slight. The average storage losses were dry matter $2-3 \%$, dig. crude protein $6-7 \%$ and starch equivalent $4-5 \%$.

The slight losses of dig. crude protein show that there was little or no heating of the hay in these experiments.

Although in our trials the average storage losses were almost the same in both methods of haymaking, in practice there will be more heating in hay made on the ground.

Our experiments showed that there were the following total losses:

$\begin{array}{lccc} & \text { dry matter } & \text { dig. crude protein } & \text { starch equivalent } \\ \text { Hay dried on the ground } \ldots \ldots \ldots & 21 \% & 33 \% & 42 \% \\ \text { Hay dried on pyramids } \ldots \ldots \ldots & 23 \% & 37 \% & 45 \%\end{array}$

It may be concluded from this data that in the Netherlands it is not necessary that the losses of feeding value involved in haymaking on the ground should be greater than those in haymaking with use of appliances. I would mention, however, that all these experiments were performed in the spring and early summer, and that the results of haymaking in the Netherlands in the late summer and autumn would probably favour the use of appliances.

I would also stress the fact that in our experiments a great deal of attention was paid to both methods of haymaking. But most Dutch farmers pay less attention to haymaking on the ground in particular, so that in practice the losses in this type of haymaking will probably be even greater than we found in our experiments. On such farms the use of racks or pyramids would also be preferable from the point of view of conservation losses. Finally, it is profitable for many Dutch farmers to obtain a better distribution of labour in haymaking by using racks or pyramids.

There is another method of haymaking which is fairly recent in the Netherlands, viz. barn drying.

In this method the hay, or rather the wilted grass containing 40 to $60 \%$ of dry matter is stored in a special drying barn where air is blown through until the hay is dry. In countries where the relative humidity of the air is usually low cold air can be used, but in the Netherlands, where the relative humidity is usually high, it is nearly always necessary to use heated air.

In this method of haymaking there are three different stages.

Before the material is transferred to the drying barn it has to be left on the field for some days in order to wilt. The duration of wilting, and hence the wilting losses, are highly dependent on the weather (15).

We then come to the second stage, viz. drying in the drying barn. The drying period varies from 1 to 4 days, depending on various factors such as the dry matter content of the hay and the amount of hay in the drying barn. During much of this time respiration not only continues, but its intensity will even be increased by the higher temperature.

After drying, the hay is transferred from the barn drier to the haystack. Since storage losses are greatly dependent on the dry matter content of the hay and hay in the barn is usually well dried, the storage losses will be slight.

During recent years we have carried out 5 experiments (14) to determine the losses which occur in this method of haymaking. Generally speaking there 
was a good agreement between the results of the various trials. The average losses of dry matter were $15 \%$, those of dig. crude protein $25 \%$, and those of starch equivalent $35 \%$.

In these trials the losses of dry matter were about $8 \%$ lower than the average losses in haymaking on racks or pyramids. In the case of dig. crude protein this difference was about $12 \%$ and in the case of starch equivalent about $10 \%$.

Moreover there is a distinct difference in the carotene content. In these trials we found an average of 20.6 p.p.m. of dry matter in the barn dried hay after storage and 7.3 p.p.m. in the comparable hay dried on racks or pyramids.

In a previous investigation (4) of the carotene content of Dutch hay we found an average of only 5.1 p.p.m. in hay from North Holland and Friesland, and an average of 13.9 p.p.m. in hay from the province of Limburg where hay is not stored in a haystack but in the loft. Even in the case of the latter hay about $95 \%$ of the carotene originally present in the grass is lost, and in the case of barn dried hay the loss will be at least $90 \%$.

Recently a further method of hay drying has been evolved in the Netherlands. In this method air is not blown through separate barn but through the haystack direct. It appears that when the moisture content is below $35 \%$ it is unnecessary to blow through warm air, and cold air can be used even in the Netherlands. We intend conducting experiments this year in order to determine the losses occurring in this method of haymaking as well.

2. We now come to a method of conservation which is related to barn drying, viz. THE ARTIFICIAL DRYING OF GRASS.

In artificial drying the moisture in the plants is quickly evaporated by the heat supplied by burning coal or oil. Moreover this drying is so complete that it is impossible for any enzymatic or bacterial conversions to occur subsequently. Owing to the rapid progress of the drying process respiration losses are very low, nor are there any losses caused by rain or the activity of microorganisms. But even in artificial drying some losses occur which we have to class as mechanical losses.

The losses in the drier may arise from the complete or partial combustion of parts of the product and loss of fine material from the exhaust gasses (25).

Although in practice it is possible that the losses will be greater than in exact experiments under favourable conditions, both BrEIREM (2) and WATSON (27) are of the opinion that the dry matter losses in artificial drying need never exceed $5 \%$. This opinion was recently confirmed by KöNEKAMP (23), who concluded from the results of his experiments that the average dry matter losses would be about $3 \%$, while Crasemann (6) assumed the average dry matter losses to be as low as $2 \%$.

When the material is dried in the proper way there will be no heating or moulding during storage, consequently the dry matter losses occurring during proper storage will be very small and probably amount to about $1 \%$. If we assume the average dry matter losses caused by drying grass to be $3 \%$ and storage losses to be $1 \%$, the total dry matter losses will then be about $4 \%$.

At the Experimental Station at Hoorn we have conducted numerous experiments relating to the decrease in digestibility caused by artificial drying. In these experiments, in which the grass was dried in low temperature driers, 
there was a negligible decrease in digestibility of most components, but there was a decrease of about $5 \%$ in the digestibility of the protein (3).

In our first experiments with grass dried in high temperature driers $(8,11$, 12) we found a greater decrease in digestibility, but in a further experiment conducted in 1953 (16) it was found that the design and the way of handling of high-temperature driers have been so improved in the Netherlands during recent years that drying grass in this type of drier yields a product which is equal to that produced by low temperature driers.

When the grass is properly dried the average decrease of the digestibility of the protein is $5 \%$. As it has been shown that there is no change in the chemical composition of the dry matter consequent upon proper artificial drying we may assume that where the average loss of dry matter is $4 \%$ the loss of protein will also amount to $4 \%$. When this is combined with the $5 \%$ decrease in the digestibility of the protein the total loss of dig. crude protein will be about $9 \%$.

We also found that proper artificial drying decreases the digestibility of the organic matter by about $1 \%$, and that when the dried material is worked up into meal or cubes the digestibility of the organic matter decreases by about $3 \%$. Thus in good grass meal or cubes the decrease in the digestibility of the organic matter will be about $4 \%$. Finally, in calculating the losses of starch equivalent we still have to take into account the decrease of "the value number". As we already mentioned in dealing with the losses of starch equivalent of hay, according to KeLLNER an increase of the crude fibre deduction factor from 0.29 to 0.58 is a good estimate of the higher energy expenditure accompanying the digestion of a dry roughage such as hay in comparison with that of grass.

When dried grass was introduced in the Netherlands and we determined the digestibility of this new product (3) we did not know which crude fibre deduction factor to use. According to KeLLNER we had to employ the factor 0.58 , but in our opinion this was too high. In the end we thought it best to compromise by choosing 0.44 as our factor, viz. the average of 0.29 and 0.58 .

In order to test this deduction factor we conducted an experiment with dairy cows fed with this artificially dried grass (7). The results of this trial show that when the correction of 0.44 was applied the starch equivalent of dried grass was approximately exact. According to this calculation the starch equivalent of good grass is decreased by about $6 \%$ as a result of artificial drying.

According to the calculation of the losses of starch equivalent caused by artificial drying of grass followed by storing, we have successively a $4 \%$ loss of dry matter, and hence also a $4 \%$ loss of organic matter, then a $1 \%$ decrease of the digestibility of organic matter and a decrease in the "value number" of over $6 \%$. Consequently the total losses of starch equivalent caused by artificial drying of grass are about $11 \%$. When the final product is delivered in the form of grass meal or cubes this value should be increased by about $3 \%$, so that the total loss of starch equivalent will be about 13 to $14 \%$.

The losses are higher when a product such as lucerne is artificially dried. This is to be expected in view of the fact that lucerne is a more stalky plant of which the fine, nutritive leaves dry more quickly than the more woody 
stems. In our trials $(17,18)$ we found a decrease of about $10 \%$ in the digestibility of the protein. Finally, when lucerne is artificially dried the dry matter losses should be put at $5 \%$, the dig. crude protein loss at $15 \%$, and the starch equivalent loss at about $16 \%$.

With a good artificial drying the carotene losses are slight. According to WATSON (27), when drying is properly carried out such losses should rarely exceed $10 \%$.

So many trials have been conducted on the subject of carotene losses during storage that there is no need for us to go into the subject here. These losses depend on various factors of which temperature is especially important. The losses are usually high, so that when the crop is stored for six months we should reckon on a carotene loss of 40 to $50 \%$ (24).

But dairy cows do not require large amounts of carotene, and I would put the amount required for one animal at about $200 \mathrm{mg}$ per day. Thus $1 \mathrm{~kg}$ of grass meal will be sufficient to meet this accepted requirement. It will therefore be advisable to increase the value of the first $\mathrm{kg}$ of grass meal, but only when the rest of the ration contains an insufficient quantity of carotene.

But when silage is fed to the cows it is unnecessary to pay special attention to the carotene because silage contains a sufficient amount to maintain the cow's supply of vitamin A.

3. And thus we come to the third main group of conservation methods, viz. : THE MAKING OF SILAGE.

There are various methods of making silage. We will first distinguish between the warm and cold method.

In what is known as the warm method ensiling takes several days and the grass is exposed to the air for some time. Respiration continues accompanied by a sizeable heat production. By applying a certain degree of desiccation an attempt is thus made to render the grass unsuitable as a substrate for bacteria and in this way the farmers hope that the silage will arrive at a certain equilibrium state.

In this method of making silage there are, in the first place, high respiration losses, and moreover the prolonged high temperature leads to a decline in the digestibility of the protein. In most cases the desirable equilibrium state is not reached and the bacteria are able to exert their harmful effect, thus resulting in further losses. The activity of putrefaction bacteria will lead to high losses of protein in particular.

In a number of these warm silages both the sides and top of which were covered with a heavy layer of soil we noted an average dry matter loss of about $17 \%$. The grass for these silages had usually been cut some days previously, as a result of which there will have been some wilting losses. If we assume these losses to be $3 \%$ we arrive at a total dry matter loss of about $20 \%$ with this warm method of making silage.

As a result of the activity of putrefaction bacteria the losses of crude protein are much higher than the dry matter losses. This together with the decrease in digestibility of the protein caused by prolonged high temperatures leads to very high losses of dig. crude protein. In our trials these losses varied from about 40 to $70 \%$, the average loss of dig. crude protein being about $55 \%$. The losses of starch equivalent in these trials varied from about 25 to $30 \%$. 
When this warm method is applied in practice, when in most cases the work is not carried out with such care and the sides of these stacksilages are uncovered, the losses are even considerably higher. In some former trials at the Agricultural Experimental Station at Hoorn (26) an average dry matter loss of $20 \%$ was found in 10 of these silages made in the ground, whereas in the case of 5 stacksilages on the ground the average dry matter loss was $32 \%$, viz. an increase of $12 \%$. Consequently the losses of dig. crude protein and starch equivalent will also be correspondingly higher.

In order to apply a cold method of ensiling it is almost essential to use a silo. The silo should be rapidly filled, the grass being firmly trampled, and after filling the grass should be immediately covered with a heavy layer of soil. In this way the crop is well pressed down and there is a minimum of enclosed air, while at the same time it is impossible for fresh air to penetrate the mass from outside. As a result respiration is quickly arrested and the silage remains cold.

In this cold method of making silage we have to distinguish between the ensiling of grass with a low and a high dry matter content.

a. Ensiling of fresh grass. As soon as the respiration of the grass is arrested by the lack of air the grass dies and the sap leaves the plant cells. This sap is a good nutrient for the numerous bacteria which are always present in fresh grass. It is obvious that the only bacteria capable of growing are those which are able to live without air, i.e. the anaerobic bacteria. The most important species are the lactic and butyric acid bacteria and the coli- and putrefaction bacteria. Which species is enabled to grow will depend on circumstances. The lactic acid bacteria are always the first to grow. They convert the sugars in the sap to lactic acid. This lactic acid fermentation has a great effect on the development of the other bacteria as the easily fermentable carbohydrates disappear, the acidity increases and the $\mathrm{pH}$ value consequently falls. This reduction of the $\mathrm{pH}$ value has a great effect on the development of putrefaction bacteria which are soon prevented from growing by the lactic acid formed. The limit of this growth is about $\mathrm{pH} 4.7$.

The butyric acid bacteria have greater powers of resistance, but when the $\mathrm{pH}$ value falls to below 4.2 , the butyric acid bacteria are also prevented from growing. The losses caused by lactic acid fermentation are slight because the lactic acid formed has a feeding value which is practically equal to that of the sugars from which it originated.

This sufficient decrease in the $\mathrm{pH}$ caused by the production of lactic acid is only obtained when the grass has an adequate sugar content. But when the lack of sugar arrests the growth of the lactic acid bacteria, and hence also the production of lactic acid, before the $\mathrm{pH}$ of the silage has reached a sufficiently low value the butyric acid bacteria are given an opportunity to develop. A part of the butyric acid bacteria are able to utilize for their growth both carbohydrates and lactic acid, as well as the lactic acid salts (lactates).

These bacteria convert the lactic acid into butyric acid and produce only one mol. of butyric acid from $2 \mathrm{~mol}$. of lactic acid. This leads to an increase in the $\mathrm{pH}$ value of the silage, and finally the putrefaction bacteria are also enabled to grow. 
This is not the case with the coli-bacteria as the latter are unable to grow in anaerobic conditions without sugar. But putrefaction bacteria do not use sugar in order to grow, but only protein. A part of the protein is broken down to ammonia, so that in this type of silage there is a regular increase of the $\mathrm{pH}$ value and the silage is increasingly spoilt.

Generally speaking this is what happens in a silage of fresh grass without addition. In our trials we found that in this type of silage the dry matter loss was about $20 \%$, the average loss of dig. crude protein about $55 \%$, and of starch equivalent about 30 to $35 \%$. These losses were practically equal to those obtained by using the warm method, except that the losses of starch equivalent are usually even slightly higher.

However, various methods are known by which these ensiling losses can be limited. One method is to stimulate the growth of the lactic acid bacteria, which are the most desirable species, or to inhibit the growth of harmful bacteria. This can be done by adding strong acids such as A.I.V.-acid or formic acid. This very soon creates a low $\mathrm{pH}$ value which prevents the harmful bacteria from growing.

Another method is to stimulate the growth of lactic acid bacteria in such a way that the considerable amount of lactic acid produced rapidly leads to sufficiently low $\mathrm{pH}$ value. This can be effected by adding sugars in the form of molasses, beet, etc.

Both methods lead to approximately the same results, viz. a $\mathrm{pH}$ value of less than 4.0 , an almost complete absence of butyric acid and a low ammonia fraction. The latter we define as the ammonia nitrogen in $\%$ of the total nitrogen, and this is a very safe criterion of the protein breakdown. In good silages of this type we found dry matter losses of about 10-15\%. Some of these losses are caused because various components dissolve in the sap and are drained off with it from the silo. The wetter the grass used for ensiling the greater will be the amount of sap that drains off and the greater the losses. This is shown by an experiment carried out by KAPPELLE (21), who found that in the case of grass having a dry matter content of $22 \%$, about $4 \%$ of the total amount of dry matter disappeared from the silo together with the draining sap, whereas the loss would have been about $10 \%$ in the case of grass containing $15 \%$ of dry matter. The losses of starch equivalent are only slightly in excess of the dry matter losses and may be estimated at about $10-15 \%$ in the case of a good A.I.V. or molasses silage. The losses of dig. crude protein in A.I.V. silages were usually somewhat lower than in grass silages made with molasses. In A.I.V. silages the dig. crude protein loss is about $20-25 \%$, and in molasses silages about 25 to $30 \%$.

If we regard all cold silages made from fresh grass, with or without the addition of A.I.V. acid, molasses, etc., as constituting a single group it may be concluded that within this group there is a relation between $\mathrm{pH}$ value and the losses of dig. crude protein and starch equivalent (13). The correlation between $\mathrm{pH}$ value and the losses of dig. crude protein is particularly close. Using a parabolic regression line it was possible to estimate that the average dig. crude protein loss was about $25 \%$ for a $\mathrm{pH}$ of 3.6 , about $35 \%$ for a $\mathrm{pH}$ of 4.2 , about $50 \%$ for a pH of 4.8 , about $60 \%$ for a $\mathrm{pH}$ of 5.2 , and about $70 \%$ for a $\mathrm{pH}$ of 5.5. The correlation between $\mathrm{pH}$ and starch equivalent is not so close, but generally speaking it may be stated that for a $\mathrm{pH}$ of 3.6 the starch 
equivalent loss will be about $15 \%$, for a $\mathrm{pH}$ of 4.2 about $20 \%$, for a $\mathrm{pH}$ of 4.8 about $26 \%$, and for a $\mathrm{pH}$ of 5.5 about $32 \%$.

b. In conclusion, there is another excellent method of making silage, viz. the wilting method. It has been demonstrated that grass silages having a high dry matter content inhibit the growth of various species of bacteria. Hence this method of ensiling reduces to a minimum the losses caused by bacteriological conversion. But this is only true when the dry matter content is sufficiently high. In order to obtain good results the grass should be homogeneously wilted on the field until the dry matter content has risen to at least $40 \%$.

For this purpose the period during which grass is wilted in Holland has to be from 2 to 3 days in fine weather, and from even 7 to 10 days in bad weather, at any rate under Dutch climatic conditions. During this period respiration continues, so that there may be great variations between the losses of dry matter on the field. In our trials (15) we found a variation in dry matter losses of from 2 to $13 \%$, depending on the time of wilting. Since the bacterial activity is low and there is no sap draining off the losses in the silo are slight. In our trials (15) the dry matter losses in the silo varied from 4 to $14 \%$, the average being about $9 \%$. The total dry matter losses varied from 11 to $21 \%$, the average being about $15 \%$.

Since bacterial activity is slight in this type of silage the crude protein losses are only slightly higher than the dry matter losses. The losses of digestible crude protein averaged about $25 \%$.

According to KELLNER a higher crude fibre deduction factor should be used in calculating the starch equivalent of this drier material. KELLNER advocates the use of a crude fibre deduction factor increasing from 0.29 to 0.58 when the crude fibre content of the material rises from 4 to $16 \%$. This factor reaches the value of 0.44 with about $10 \%$ of crude fibre.

In making our calculation of starch equivalent we followed KeLLNER's method of correction when the crude fibre content was below $10 \%$, but when the silage contained more than $10 \%$ of crude fibre we used the deduction factor of 0.44 , in the same way as we did in the case of artificially dried grass.

As a result of this higher crude fibre deduction the starch equivalent loss is somenwhat higher than the dry matter loss. In our trials they averaged about 25 to $30 \%$.

With a cold method of ensiling the carotene losses in the silo are slight. Even when wet grass is ensiled without any addition and the air is excluded much of the carotene is preserved intact.

But when wilted grass is ensiled part of the carotene has been lost during wilting even before ensilage takes place.

In comparative experiments we found that molasses silages had a carotene content of about 230 p.p.m. parts of dry matter and the wilted silage about 140 p.p.m.

The losses of carotene in a warm silage greatly depend on the temperature, but they will generally be high.

At this point we will also give some data concerning the vitamin $\mathrm{D}$ content of the various grass products. The determination of vit. D is not as simple as that of carotene, so that the available data are limited. 
In his thesis published in 1955 WeITs (28) provides us with information on the antirachitic activity of Dutch roughages.

He found little or no difference in the vitamin D content of the various types of silages. The grass silages contained an average of about 300 I.U. of vitamin $\mathrm{D}$ per $\mathrm{kg}$ of dry matter.

$\mathrm{He}$ found that artificially dried grass contained an average of about $500 \mathrm{I} . \mathrm{U}$., but if one very high value is omitted the average value becomes 340 . Consequently grass silage and artificially dried grass have about the same vitamin $\mathrm{D}$ content.

The highest vitamin $\mathrm{D}$ content was found in hay cured in windrows and cocks. In this hay he found an average of 1000 I.U. of vitamin D per $\mathrm{kg}$ of dry matter. In hay dried on pyramids or racks he found an average value of nearly 600 , or about 800 I.U. if one very high value is included.

These findings confirm the conclusion that there is a correlation between the vitamin $\mathrm{D}$ content and the time the products are exposed to sunlight during curing.

When, finally, the losses of dry matter, dig. crude protein and starch equivalent in the various conservation methods are summarized in one table, the results are as follows.

\begin{tabular}{|c|c|c|c|}
\hline & \multicolumn{3}{|c|}{ Average losses $(\%)$ of : } \\
\hline & dry matter & dig. crude protein & starch equivalent \\
\hline Haymaking : & & & \\
\hline $\begin{array}{l}\text { dried on the ground } \ldots \ldots \ldots \\
\text { dried on pyramids or racks } \ldots \\
\text { dried in a barn } \ldots . . . . . .\end{array}$ & $\begin{array}{l}21 \\
23 \\
15\end{array}$ & $\begin{array}{l}33 \\
37 \\
25\end{array}$ & $\begin{array}{l}42 \\
45 \\
35\end{array}$ \\
\hline 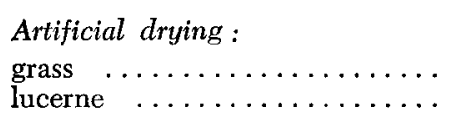 & $\begin{array}{l}4 \\
5\end{array}$ & $\begin{array}{r}9 \\
15\end{array}$ & $\begin{array}{l}13 \\
16\end{array}$ \\
\hline $\begin{array}{l}\text { Ensiling: } \\
\text { warm method } \ldots \ldots \ldots \ldots \ldots \\
\text { cold method: }\end{array}$ & 20 & 55 & $25-30$ \\
\hline $\begin{array}{l}\text { a. without addition } \ldots \ldots \ldots \\
\text { b. with A.I.V. acid } \ldots \ldots \ldots \ldots \\
\text { c. with molasses } \ldots \ldots \ldots \ldots \\
\text { d. wilting method } \ldots \ldots \ldots \ldots\end{array}$ & $\begin{array}{c}20 \\
10-15 \\
10-15 \\
15\end{array}$ & $\begin{array}{c}55 \\
20-25 \\
25-30 \\
25\end{array}$ & $\begin{array}{l}30-35 \\
10-15 \\
10-15 \\
25-30\end{array}$ \\
\hline
\end{tabular}

Artificial drying is the conservation method which gives the lowest losses. Next comes ensiling of fresh grass with addition of A.I.V. acid or molasses, and then the well-made wilted silages.

If we only take into consideration the dig. crude protein losses, barn drying would come immediately after the wilted silage, followed by the other methods of haymaking. The warm and cold ensiling method without addition comes last of all.

But when we consider the losses of starch equivalent the various methods of haymaking come last of all. 
Haymaking is a conservation method which is attended by great losses of feeding value and is greatly dependent on weather conditions. Furthermore, most haymaking methods require a great deal of labour.

It has therefore been quessed whether in future it might be possible to make only silage from our grass, and omit haymaking. This means that the winter roughage rations of the cows would not contain hay, and in many cases would only consist of silage.

In order to study the consequences of giving such a roughage ration, during the last two winters we have been conducting feeding trials with dairy cows at the Agricultural Experimental Station at Hoorn.

In the autumn these animals were first given fresh grass in the cow-house, afterwards fresh grass and silage, and finally, during winter, silage only supplemented by the amount of concentrates they needed to maintain milkproduction. There were even cows that were given no concentrates at all for some weeks.

The quantity of silage eaten by the cows obviously depended on its dry matter content. The animals ate quantities varying from 79 to $115 \mathrm{lbs}$. a day each (the average being 96 lbs. a day) of a good grass silage made with the addition of molasses and containing $25 \%$ of dry matter. When a silage of this type contained $20 \%$ of dry matter the amounts consumed were even higher, varying from 97 to $132 \mathrm{lbs}$., with an average of $113 \mathrm{lbs}$. of silage per cow per day. Generally speaking the results of this silage feeding were satisfactory. The results of feeding wilted silage were even good. When we fed grass silages with molasses we found that milk production was still good during the last winter but there was a decrease of about $0.5 \%$ in the fat percentage of the milk.

When we fed a poor silage to the animals the milk and butter not only had an offensive smell and taste, but a great deal of acetone was found in the animals' urine.

Thus when you wish to give your cows a ration containing large amounts of silage this is only feasible with a good silage containing little or no butyric acid.

The exact reason why the fat percentage of the milk decreases is still unknown.

\section{REFERENCES}

V.L.O. = Verslagen landbouwkundige Onderzoekingen.

J.P. $\quad=$ Jaarverslag Proefzuivelboerderij te Hoorn. (Annual report Experimental Dairyfarm at Hoorn).

I Brandsma, S. and N. D. Dijkstra: Enige onderzoekingen over de verliezen bij hooiwinning. V.L.O. 62.14 (1956).

2 Breirem, K.: Kunstig tørking av gras. Landbruksh $ø$ gskolens Inst. f. Husdyremaring, Saertrykk 58 (1947).

3 Brouwer, E. and N. D. Dijkstra: Verteerbaarheid en voederwaarde van kunstmatig gedroogd gras. V.L.O. 45 (1939) 119 ; J.P. (1938) 177.

4 -,$-\ldots$ : Over het gehalte van hooi en stro aan carotine. V.L.O. 47 (1941) 1275 ; J.P. (1941) 83.

5 Crasemann, E.: Untersuchungen über Futterkonservierung. Landw. Versuchsstat. 102 (1924) 123.

6 - - : Uber Grünfutterkonservierung mit besonderer Berücksichtigung der künstlichen Trocknung. Landw. Jahrbuch 31 (1954) 1. 
7 Dijkstra, N. D. : Voederproef met melkvee omtrent de voederwaarde van kunstmatig gedroogd gras. V.L.O. 45 (1939) 617 ; J.P. (1939) 95.

8 - - : Voederproef met graslandprodukten, zonder gebruikmaking van enig krachtvoer, bij melkvee. V.L.O. 49 (1943) 29 ; J.P. (1942) 63.

9 - - : Vergelijkende onderzoekingen over de verliezen bij hooiwinning op de grond en met behulp van ruiters. V.L.O. 53 (1947) 51 ; J.P. (1946) 3.

10 - - : Vergelijkende voederproef met hooi en A.I.V.-zuur silage bij melkvee. V.L.O. 54.9 (1949) 17 ; J.P. (1947).

11 - - : Verteerbaarheid en voederwaarde van kunstmatig gedroogd gras. V.L.O. 54.11 (1948); J.P. (1947).

12 - - : The influence of artificial drying on the digestibility of grass. Report VIIIth Intern. Congress of Agr. Ind. (Brussel, 1950).

13 - - : De grote betekenis van de $\mathrm{pH}$ voor het silageproces. Landbouwk. Tijdschr. 62 (1950) 190.

14 - -: Onderzoek naar de verliezen bij de hooiwinning volgens de z.g. schuurhooimethode (still in press).

15 - - and S. Brandsma: Proefnemingen over het ensileren van voorgedroogd gras. V.L.O. 61.3 (1955); J.P. (1954).

16 - - and J. J. I. Sprenger : Proefnemingen over de achteruitgang van de verteerbaarheid bij het kunstmatig drogen van gras. V.L.O. 61.1 (1955); J.P. (1954).

$17--,-$, : Proefnemingen over de achteruitgang van de verteerbaarheid bij het kunstmatig drogen van luzerne I. V.L.O. 61.11 (1955); J.P. (1955).

18 -,$- \ldots$ : Proefnemingen over de achteruitgang van de verteerbaarheid bij het kunstmatig drogen van luzerne II. V.L.O. 62.11 (1956).

19 - - and D. van DER SchaAF: Onderzoek naar de voederwaarde van gebroeid hooi. V.L.O. 61.15 (1955); J.P. (1955).

$20,-, \ldots$ : Onderzoek naar de voederwaarde van gebroeid hooi II. V.L.O. 63.9 (1957).

21 Kappelue, D. : Het droge-stofgehalte van in te kuilen materiaal en de verliezen met het perssap. Maandbl. Landbouwvoorlichtingsdienst 9 (1952) 146.

22 Kellner, O. and A. Scheunert : Grundzüge der Fütterungslehre (Berlin, 1952) 280.

23 KöneKamp, A. H. : Die drei Konservierungsverfahren. Futterkonservierung (1955) 65.

24 LENKEIT, W. : Die Bedeutung der künstlich getrockneten Futtermittel in der Leistungsfütterung. Arch. D.L.G. 10 (1953) 121, referred in (6).

25 Rammlen: Zusammenfassender Bericht über Trocknungsversuche mit Luzerne und Rübenblättern an einem Büttner-Schnellumlauftrockner in der Zuckerfabrik Stöbnitz. Schriften R.K.T.L. 86 (1940) 122.

26 Ruyter de Wildt, J. C. de, E. Brouwer and N. D. Dijkstra : Proefnemingen omtrent inkuiling met en zonder toevoeging van mineraalzuur II. V.L.O. 40 (1934) 611; J.P. (1933) 187.

27 Watson, S. J. : Grassland and grasslandproducts (London, 1951).

28 Werrs, J.: De antirachitische werking van Nederlandse ruwvoeders in verband met het antagonisme tussen caroteen en vitamine D. Thesis Wageningen (1956).

29 Wiegner, G. : Heubereitung und Silage. III. Grünland Kongress (1934) 320. 